\title{
KESIAPAN LULUSAN SEKOLAH KEJURUAN SEBAGAI TENAGA KERJA YANG BERKARAKTER PROFESIONAL DAN MANDIRI
}

\author{
Ittihad \\ STIT Palapa Nusantara Lombok NTB \\ ittihadkalijaga@gmail.com
}

\begin{abstract}
Developing a profesional culture in schools is done by: (1) implementing a strict new student admission system, (2) school orientation activities on new students, (3) imposing school rules and compensation tasks, (4) implementing a solid learning system, and (5) implementing graduate marketing. Positive habits that form the basis of profesional culture can grow and develop in Shaykh Zainuddin NW Anjani Vocational School starting with the process of internalizing the noble values of profesional culture in students and teachers alike. In students the internalization process occurs because of things as follows: (1) instilling awareness about profesional cultural values by teachers and school leaders, (2) students' internal factors (encouragement from themselves), and (3) adjusting themselves to an environment that has been cultured profesionally. In the teacher the process occurs because: (1) the adaptation of the teacher to the tasks of the environment, (2) the employment status has, and (3) their assumption that carrying out the duties as a teacher is "devotion".
\end{abstract}

Keywords: Profesional Culture, Positive Habits and Internalizing Good V alues

\begin{abstract}
Abstrak: Mengembangkan budaya profesional di sekolah dilakukan dengan: (1) menerapkan sistem penerimaan siswa baru yang ketat, (2) kegiatan orientasi sekolah pada siswa baru, (3) memberlakukan tata tertib sekolah dan tugas kompensasi, (4) melaksanakan sistem pembelajaran yang mantap, dan (5) melaksanakan pemasaran lulusan. Kebiasaan positif yang menjadi dasar budaya profesional dapat tumbuh dan berkembang di SMK Syaikh Zainuddin NW Anjani dimulai dengan proses internalisasi nilai-nilai luhur budaya profesional tersebut pada diri siswa maupun guru. Pada diri siswa proses internalisasi tersebut terjadi karena hal-hal sebagai berikau: (1) penanaman kesadaran tentang nilai-nilai budaya profesional oleh gurudan pimpinan sekolah, (2) faktor internal siswa (dorongan dari diri sendiri), dan (3) penyesuaian diri dengan lingkungan yang telah berbudaya profesional. Pada guru proses tersebut terjadi karena: (1) adaptasi guru terhadap tugas-tugas lingkungannya, (2) dimilikinya status kepegawaian, dan (3) anggapan mereka bahwa melaksanakan tugas sebagai guru merupakan "pengabdian".
\end{abstract}

Kata Kunci: Budaya Profesi, Kebiasaan Positif dan Menginternalisasi nilai-nilai Baik

Fondatia : Jurnal Pendidikan Dasar

Volume 3, Nomor 2, September 2019; 89-102

https://ejournal.stitpn.ac.id/index.php/fondatia 


\section{PENDAHULUAN}

Sumber daya manusia yang mampu berperan sebagai faktor keunggulan kompetitif adalah yang menguasai ilmu pengetahuan dan teknologi, memiliki keterampilan yang tinggi, berperilaku profesional dan dapat mengembangkan diri ${ }^{1}$. Pendidikan Sekolah Kejuruan sebagai sub sistem dari pendidikan nasional berperan penting dalam menyiapkan sumber daya manusia yang berkualitas profesional SMK Syaikh Zainuddin Nahdlatul Wathan Anjani harus dapat menyiapkan lulusannya sebagai calon tenaga kerja yang profesional. Untuk itu SMK, dituntut untuk dapat Mengembangkan mutu dan relevansinya. Salah satu langkah yang diambil Pendidikan SMK Syaikh Zainuddin Nahdlatul Wathan Anjani dalam rangka Mengembangkan mutu dan relevansinya adalah mendorong semua SMK Syaikh Zainuddin Nahdlatul Wathan Anjani agar dapat berfungsi sebagai "Pusat Pengembangan Budaya Profesional". Banyak faktor yang dapat mempengaruhi berkembangnya budaya profesional di SMK Syaikh Zainuddin Nahdlatul Wathan Anjani. Faktor-faktor yang berkaitan dengan jalannya proses pembelajaran di SMK Syaikh Zainuddin Nahdlatul Wathan Anjani sangat mempengaruhi Pengembangan budaya profesioanal tersebut. Faktor kepala Sekolah, guru, karyawan, kepemimpinan, administrasi dan pengelola sekolah diduga juga dapat mempengaruhi berkembangnya budaya profesional di SMK. Budaya profesional tersebut tidak muncul begitu saja tetapi perlu ditumbuh kembangkan.

Perilaku-perilaku profesional di SMK tidak lepas dari faktor guru dan kepemimpinan Sekolah. Guru merupakan komponen sekolah yang berhubungan langsung dengan siswa terutama melalui proses belajar mengajar (PBM). Dalam proses belajar mengajar guru berinteraksi dengan siswa. Sesuai dengan tugasnya, perilaku guru akan mempengaruhi perilaku siswa. Guru cenderung menjadi contoh bagi siswanya. Dari hal-hal tersebut diatas diperkirakan guru mempunyai andil yang besar dalam menanamkan kebiasaan-kebiasaan kepada siswa.

Salah satu dari SMK SZ NW Anjani yang ada di Kab Lombok Timur yang telah melaksanakan budaya profesional adalah SMK Syaikh Zainuddin NW Anjani. SMK kebiasaan-kebiasaan yang menjadi dasar perilaku profesional seperti diuraikan dimuka telah terlaksana dengan baik. Hal tersebut terbukti dari survai pendahuluan dapat diketahui beberapa hal penting berkaitan dengan : kedisiplinan, kebersihan, dan tertib administrasi. SMK SZ NW Anjani terdapat 'keunikan' apabila dibandingkan dengan SMK lain di Kab Lombok Timur, khususnya dalam mengembangkan budaya profesional. Hal yang khas

${ }^{1}$ Thoha, Miftah, Kepemimpinan dalam Manajemen. (Jakarta : Rajawali Pers.1990), hlm. 
tersebut dianggap sebagai suatu kasus kelembagaan. Dalam hal ini berupa kasus keberhasilan dari SMK Syaikh Zainuddin NW Anjani dalam mengembangkan budaya profesional. Meskipun demikian sampai saat ini di SMK Syaikh Zainuddin NW Anjani belum pernah dilakukan penelitian tentang hal tersebut. Oleh karena itu kasus keberhasilan tersebut perlu dikaji lebih dalam. Untuk mengungkap dan mendiskripsikan semua permasalahan yang terkait dengan mengapa di SMK Syaikh Zainuddin NW budaya profesional tersebut dapat ditumbuhkembangkan, maka sangat perlu dilakukan penelitian yang mendalam melalui studi kasus.

Berdasarkan latar belakang tersebut, maka dapatlah dikemukakan bahwa yang menjadi permasalahan adalah: (a) faktor apakah yang mempengaruhi guru dalam berperan aktif mengembangkan budaya profesional di SMK Syaikh Zainuddin NW?, (b) mengapa kebiasaan-kebiasaan profesional dapat tumbuh dan berkembang di SMK Syaikh Zainuddin NW Anjani?

Tujuan yang hendak dicapai dalam penelitian ini adalah: (a) mengungkap dan mendeskripsikan faktor-faktor yang mempengaruhi guru dalam berperaaktif mengembangkan budaya profesional di SMK Syaikh Zainuddin NW AnjaniNW Anjani, (b) Mengungkap dan mendeskripsikan alasan kebiasaan-kebiasaan profesional dapat tumbuh dan berkembang di SMK Syaikh Zainuddin NW.

Pengertian Budaya Profesional. Sebelum membahas budaya profesional terlebih dahulu perlu dikemukakan makna dari kata "budaya" dan "profesional". Budaya dapat diartikan sebagai praktek-praktek dalam masyarakat dan kehidupan individu yang mengandung nilai intrinsik (moral). Dalam arti sempit, budaya dapat diartikan sebagai suatu kebiasaan atau tradisi. Sedangkan profesional berasal dari profession yang artinya pekerjaan. Profesional adalah suatu kondisi kemampuan bekerja di bidang tertentu yang mempersyaratkan kualitas tinggi dan tidak setiap orang dapat melakukannya ${ }^{2}$. Seseorang dapat diklasifikasikan profesional apabila memiliki ciri-ciri: (a) menampilkan performa kerja yang cepat, tepat dan efisien pada pekerjaan yang sesuai dengan keahliannya; (b) proses dan produk kerjanya memenuhi standar nilai profesi; dan; (c) pekerjaan yang sesuai bidang keahliannya memberi makna yang berarti. Seorang profesional digerakkan lebih oleh bisikan hati untuk berbuat sebaik-baiknya dari pada oleh kepentingan pribadi. Jadi seorang yang profesinal, dalam keadan bagaimanapun harus memberikan jasa yang paling bermutu. Dari pengertian di atas, budaya profesional dapat diartikan sebagai kebiasaan bekerja

${ }^{2}$ J. Pakpahan dan Narsoyo, 1990 
dengan tataran kemampuan yang tinggi dan dilandasi oleh nilai-nilai intrinsik (moral) ${ }^{3}$. Tujuan Pengembangan Budaya Profesional. Pembentukan budaya profesional, pada hakikatnya dimaksudkan untuk Mengembangkan kualitas hidup seseorang menjadi hidup yang bermakna. Hidup dikatakan bermakna bagi seseorang apabila orang tersebut: (a) taqwa kepada Tuhan Yang Mahaesa; (b) bangga dan senang atas keahlian dan pekerjaannya; dan (c) berguna bagi sesama manusia.

Prinsip-prinsip Pengembangan Budaya Profesional. Budaya yang mencakup sikap, nilai serta perilaku dapat ditumbuhkan melalui pendidikan di sekolah. Dalam menumbuhkan suatu budaya harus ada norma, aktivitas dan materi. untuk menumbuhkan budaya profesional harus melalui beberapa tahapan. Pertama, adalah membuat dan memberlakukan tata tertib yang membiasakan siswa berperilaku profesional. Kedua, adalah memberi pengertian, pelatihan dan usaha untuk mencapai keahlian profesional. Ketiga, adalah memberikan contoh perilaku profesional oleh kepala sekolah, guru dan pegawai atau karyawan sekolah.

Mengembangkan budaya profesional memerlukan waktu yang lama. Pengembangan budaya profesional melalui sekolah merupakan bagian dari total processs yang panjang. Pengembangan budaya profesional mengikuti proses dengan tahapan: (a) internalisasi nilainilai luhur budaya profesional; (b) internalisasi nilai-nilai luhur akan membentuk sikap profesional; (c) sikap profesional mempengaruhi orang berperilaku profesional. Proses internalisasi nilai-nilai luhur budaya profesional adalah proses pembentukan mental ${ }^{4}$. Hal tersebut dimulai dengan meletakkan dasar-dasar kepatuhan dan ketekunan. Proses selanjutnya adalah pemberian dasar-dasar khusus yang sesuai dengan bidangnya. Pada proses ini menanamkan bagaimana melakukan tugas atau kegiatan yang baik dan dilandasi dengan pemahaman teori yang mantap. Langkah terakhir proses Pengembangan budaya profesional adalah kegiatan nyata dalam kondisi sebenarnya. Misalnya lembaga pendidikan.

Karakteristik Lulusan SMK yang Berbudaya Profesional. Sasaran utama dari Pengembangan budaya profesional di SMK adalah lulusan yang berbudaya profesional. Lulusan SMK yang berbudaya profesional memiliki karakteristik yang berbeda dari lulusan lain. Lulusan SMK yang berbudaya profesional tersebut merupakan produk dari Pengembangan budaya profesional. karakteristik lulusan SMK yang berbudaya profesional

${ }^{3}$ Hidayat, M. Arief dkk.. Studi Tingkat Profesional Guru dalam Menghadapi Fungsionalisasi Jabatan bagi Guruguru SMTA di Lingkungan Departemen Pendidikan dan Kebudayaan Daerah Istimewa Yogyakarta. FPTK IKIP Yogyakarta. 1990. Hlm.

${ }^{4}$ Sahertian, A. Profil Pendidik Professional (Yogyakarta : Andi Offset, 1994) hlm. 
meliputi: (a) menampilkan kebiasaan berdisiplin yang baik; (b) tanpa diawasi oleh orang lain selalu berusaha bekerja dengan cara yang cepat, tepat dan efisien; (c) atas usaha sendiri selalu berupaya memelihara dan Mengembangkan keahliannya; (d) memiliki rasa bangga serta cinta kepada pekerjaan dan profesinya; (e) tidak menyalahgunakan keahliannya sehingga merugikan orang lain; (f) menghargai dan menghormati teman seprofesi; dan ( $\mathrm{g}$ ) memiliki sistem nilai yang sesuai dengan profesi.

\section{METODE PENELITIAN}

Pendekatan dalam penelitian ini adalah studi kasus. Dengan pendekatan studi kasus, akan dapat dilihat secara mendalam suatu fenomena melalui metode observasi. Metode observasi yang digunakan adalah observasi langsung yaitu mengamati secara langsung tentang kejadian-kejadian dalam proses kehidupan sekolah ${ }^{5}$. menyatakan pada penelitian pendidikan banyak hal yang dapat diukur melalui observasi, seperti tingkah laku siswa pada waktu belajar, tingkah laku guru pada waktu mengajar dan sebagainya. Melalui pengamatan dapat diketahui bagaimana sikap dan perilaku individu. Dengan studi kasus juga dapat dilihat secara intensif tentang keadaan temporer yang aktual berkaitan dengan peristiwa dan interaksi fenomena di sekolah baik secara individu, kelompok maupun istitusi.

Pada studi kasus ini peneliti mengumpulkan data berdasarkan situasi yang wajar, langsung, apa adanya, dan tanpa dipengaruhi unsur-unsur lain dari luar lingkungan. Untuk itu peneliti berhubungan langsung dengan situasi dan sumber informasi (informan). Peneliti mengadakan obervasi langsung, wawancara terstruktur dan studi dokumentasi. Dengan teknik tersebut dari penelitian ini diperoleh data-data deskriptik yang berupa catatan-catatan lapangan dan hasil wawancara serta data yang berupa frekuensi kejadian dari observasi dan studi dokumentasi ${ }^{6}$.

Penelitian ini dilaksanakan di SMK Syaikh Zainuddin Nahdlatul Wathan Anjani Kec Suralaga Kab Lombok Timur. SMK Syaikh Zainuddin Nahdlatul Wathan dipilih sebagai latar penelitian karena memiliki beberapa keunikan apabila dibandingkan dengan SMK lain di Kab Lombok Timur. Pertama, peneliti melakukan observasi pendahuluan. Pada langkah ini peneliti mengadakan pengamatan tentang proses pendidikan yang dilaksanakan di SMK Syaikh Zainuddin Nahdlatul Wathan Anjani baik proses pembelajaran maupun situasi dan iklim sekolah. Hasil observasi ini untuk menentukan kelayakannya sebagai tempat

\footnotetext{
${ }^{5}$ Nana Sudjana dan Ibrahim, Penelitian dan Penilaian Pendidikan. (Bandung: Sinar Baru, 1989), hlm.

${ }^{6}$ Moleong, J Lexy. Metodologi penelitian kualitatif. (Bandung : PT. Remaja Rosdakarya, 2000) hlm.
} 
penelitian. Pada langkah ini pula peneliti mengadakan pendekatan dengan pihak sekolah dalam hal ini Kepala Sekolah, tentang kesediaan SMK Syaikh Zainuddin NW Anjani dijadikan subyek penelitian.

Kedua, Berdasarkan hasil observasi pendahuluan bahwa SMK Syaikh Zainuddin NW Anjani bersedia untuk subyek penelitian dan layak diteliti. Ketiga, mengumpulkan data dengan observasi langsung, wawancara terstruktur dan studi dokumentasi. Pengamatan langsung dilakukan oleh peneliti sendiri di kelas, maupun di ruang guru. Hal ini dimaksudkan untuk mendapatkan data tentang segala kegiatan yang dilakukan guru dan siswa dalam proses belajar mengajar. Pengamatan dengan chek list dilakukan oleh peneliti untuk mendapatkan data-data tentang iklim dan aktivitas sekolah.

Pengamatan ini dilaksanakan pada jam masuk dan jam pelajaran berakhir. Kadangkadang juga dilaksanakan pengamatan pada jam-jam pelajaran berlangsung maupun pada waktu istirahat. Wawancara terstruktur dilaksankan di ruang kepala sekolah, ruang guru, di ruang BP wawancara dilakukan kepada Kepala Sekolah,. Bagian pengajaran, bagian kesiswaan, guru dan juga kepada siswa. Wawancara ini untuk memperoleh data-data tentang proses pembelajaran, evaluasi belajar, manajemen, administrasi, kesejahteraan guru dan karyawan, kebersihan lingkungan, dan penerapan tata tertib. Studi dokumentasi dilakukan terhadap arsip-arsip atau catatan tentang struktur organisasi sekolah, kegiatan sekolah, hasil evaluasi belajar, penerimaan siswa baru dan hubungan masyarakat.

Keempat, langkah berikutnya adalah tahapan verifikasi data. Data yang telah terkumpul dari hasil observasi, wawancara dan studi dokumentasi dirangkum dan dianalisis. Hasil analisis tersebut juga didiskusikan kembali kepada informan untuk mendapatkan koreksi.

\section{HASIL DAN PEMBAHASAN}

Dalam menumbuh kembangkan kebiasaan-kebiasaan profesional di SMK Syaikh Zainuddin NW Anjani, peranan manusia pelaku pendidikan amatlah dominan. Siswa akan terbiasa berperilaku profesional tidak lepas dari campur tangan dan teladan yang diberikan oleh guru, kepala sekolah, para wakil kepala sekolah dan karyawan di sekolah tersebut.

Peranan Guru. Peranan guru SMK Syaikh Zainuddin NW Anjani dalam mengembangkan budaya profesional dilakukan sesuai dengan tugas dan jabatannya. Sebagai pengajar dan pendidik guru-guru memberikan contoh perilaku profesional dengan menampilkan diri pada tingkat kompetensi yang tinggi. Contoh perilaku profesional 
tersebut antara lain disiplin, tanggung jawab, etos kerja, dan komitmen yang tinggi terhadap tugasnya. Dalam pembelajaran, guru-guru SMK Syaikh Zainuddin NW Anjani sering memberikan pengarahan-pengarahan tentang pentingnya berperilaku profesional dan memiliki mental yang baik. Hal tersebut dilakukan dengan menghubungkannya kepada profil tenaga kerja yang dibutuhkan oleh dunia industri. Guru-guru tersebut juga berusaha menumbuhkan motivasi belajar dan bekerja pada diri siswa.

Untuk itu guru-guru SMK Syaikh Zainuddin NW Anjani selalu berupaya menciptakan situasi kelas dan situasi bengkel yang menyenangkan. Disamping itu di dalam pembelajaran guru-guru menerapkan berbagai metode mengajar yang bertujuan agar siswa dapat menguasai materi pelajaran sebanyak banyaknya. Untuk itu guru-guru tersebut bersedia meningkatkan kemampuan yang dimilikinya. Evaluasi yang obyektif dilaksanakan guru-guru SMK Syaikh Zainuddin NW Anjani terbukti dapat meningkatkan motivasi siswa dalam belajar sehingga kualitas hasil pembelajaran meningkat. Guru-guru di SMK Syaikh Zainuddin NW Anjani menerapkan peraturan dengan tegas, lebih-lebih dalam pembelajaran praktek.

Di dalam pembelajaran praktek guru-guru benar-benar membimbing siswa, antara lain dengan memberi contoh disiplin, mendemontrasikan suatu ketrampilan, mengawasi praktek dan menilai hasil praktek siswa. Ketentuan praktek di bengkel benar-benar ditegakkan. Guru-guru praktek juga berperan menyediakan semua sarana pembelajaran praktek di bengkel. Hal tersebut dilaksanakan dengan menyiapkan alat dan mesin sehingga siap pakai, bahan praktek yang cukup. Di dalam kegiatan orientasi bagi siswa baru, guru-guru SMK Syaikh Zainuddin NW Anjani berperan aktif membimbing siswa. Karena hampir semua guru terlibat dalam kegiatan tersebut, maka semua guru ikut berperan dalam pembimbingan terhadap siswa tersebut.

Peranan guru-guru dalam Orientasi Siswa Baru adalah memperkenalkan tata tertib dan budaya SMK Syaikh Zainuddin NW Anjani, memberi contoh perilaku disiplin, memberlakukan tata tertib dan sangsi dengan tegas, membina mental siswa serta membentuk pribadi yang luhur. Di dalam penerimaan siswa baru, guru-guru SMK Syaikh Zainuddin NW Anjani berperan melaksanakan sistem seleksi yang obyektif dan berdasarkan kemampuan. Sehingga dari kegiatan tersebut diperoleh siswa baru yang berkualitas. Siswa yang demikian akan mudah dibina sehingga berperilaku profesional sebagai salah satu budaya di SMK Syaikh Zainuddin NW Anjani. Sebagai wali kelas, guruguru berperan memberikan pelayanan sebaik-baiknya kepada siswa disamping juga 
membina mental siswa. Namun sebagai wali kelas peranan guru yang menonjol adalah di dalam membantu memecahkan masalah yang dihadapi siswa.

Dengan pemecahan masalah yang tepat akan menyebabkan siswa tersebut dapat kembali berkonsentrasi terhadap pelajaran di sekolah. Sebagai pembina upacara, guru-guru SMK Syaikh Zainuddin NW Anjani berperan memberikan pengarahan tentang perilaku disiplin, tanggung jawab, suka bekerja keras, tenggang rasa, giat belajar dan berbudi luhur. Sedangkan sebagai pendamping kunjungan industri, guru-guru berperan menambah wawasan industrial siswa.

\section{Peranan Kepemimpinan Sekolah.}

Wujud nyata dari peranan kepemimpinan sekolah dalam mengembangkan profesional dapat dilihat dari peranan masing-masing personil pimpinan sekolah. Peranan dari pimpinan tersebut dibahas sebagai berikut. Peranan Kepala Sekolah. Kepemimpinan kepala sekolah tidak diragukan lagi peranannya dalam mengembangkan budaya profesional, sebab kepala sekolah mengkoordinir seluruh kegiatan di sekolah. Kepala SMK Syaikh Zainuddin NW Anjani memberi contoh berperilaku profesional.

Kepala sekolah telah berusaha mengembangkan kemampuan guru sehingga mengarah ke tingkat profesional. Sebab guru yang demikian yang dapat mendorong usaha mengembangkan budaya profesional di sekolah. Untuk menjadi profesional di samping hal tersebut di atas, pada diri guru juga harus timbul motivasi dan dedikasi yang tinggi. Maka kepala sekolah selalu memperjuangkan tingkat kesejahteraan guru, sebab mereka bisa berkonsentrasi dalam melaksanakan tugas apabila kesejahteraannya dijamin. Kepala SMK Syaikh Zainuddin NW Anjani selalu memotivasi guru dalam bekerja.

Ada bermacam-macam langkah yang sudah ditempuh oleh kepala sekolah. Langkahlangkah tersebut antara lain kepala sekolah menilai unjuk kerja guru secara obyektif, penggajian yang tidak terlambat. Kepala SMK Syaikh Zainuddin NW Anjani mengusahakan suasana kesejawatan dan kekeluargaan di antara semua pegawainya. Hubungan yang baik dan harmonis telah diciptakan. Juga telah diberikan penghargaan kepada guru/karyawan yang pantas menerima.

Dari hal-hal tersebut ternyata kepala sekolah berhasil menciptakan suasana kerja yang menyenangkan. Pembinaan terhadap guru dan karyawan dilaksanakan Kepala SMK Syaikh Zainuddin NW Anjani dengan pendekatan yang manusiawi. Kepala sekolah telah menghindarkan bentuk pembinaan yang menegangkan. Dengan cara demikian guru yang 
melakukan kesalahan dengan kesadaran sendiri akan memperbaikinya. Kepala sekolah memberi kebebasan penuh kepada guru untuk melaksanakan tugas pembelajaran sesuai dengan bidangnya masing-masing. Yang lebih utama menurut Kepala Sekolah SMK Syaikh Zainuddin NW Anjani adalah kualitas pembelajaran yang tinggi. Guru-guru SMK Syaikh Zainuddin NW Anjani dalam hal mengajar selalu berusaha menciptakan suasana kelas yang kondusif. Hal tersebut telah dilaksanakan dengan langkah-langka: disiplin, melaksanakan tugas sesuai tata tertib sekolah, menerapkan metode tanya jawab serta penilaian hasil belajar siswa secara obyektif.

Dengan suasana kelas yang demikian pada diri siswa timbul motivasi yang besar untuk belajar dan suasana kelas menjadi lebih kompetitif. Guru-guru tersebut juga berusaha selalu meningkatkan kemampuan mengajarnya untuk menuju ke tingkat yang profesional. Peranan Kurikulum. Peranan Wakil Kepala Sekolah Bidang Kurikulum dalam mengembangkan budaya profesional diwujudkan dengan menyusun jadwal mengajar serta menentukan guru pengampu pelajaran yang tepat. Sebab dengan urutan mata pelajaran yang tepat tiap-tiap harinya akan mempengaruhi kualitas pembelajaran hari itu. Hal tersebut telah dilaksanakan oleh Wakil Kepala Sekolah Bidang kurikulum SMK Syaikh Zainuddin NW Anjani dan terbukti siswa selalu bisa berkonsentrasi terhadap semua mata pelajaran.

Apabila urutan pelajaran tidak baik tentu akan menimbulkan kejenuhan bahkan kelelahan pada diri siswa. Dengan terjadinya hal demikian akan menyebabkan pembalajaran di kelas tersebut tidak berhasil. Guru pelajaran yang tepat sesuai kemampuan akan meningkatkan kualitas pembelajaran. Hal tersebut mampu menaikkan tingkat penguasaan materi pembelajaran oleh siswa. Yang lebih penting lagi adalah guru benar-benar menguasai bidangnya sehingga dalam menyampaikan pembelajaran menjadi lebih bermutu. Peranan yang lain dari Wakil Kepala Sekolah Kurikulum adalah mengatur kegiatan peningkatan guru secara berkala. Sebab untuk mengembangkan budaya profesional siswa diperlukan guruguru yang mempunyai kemampuan tinggi di dalam bidangnya. Peranan Wakil Kepala Sekolah Kesiswaan. Bidang Kesiswaan di SMK Syaikh Zainuddin NW Anjani dalam memberlakukan tata tertib sekolah berperan menentukan sangsi-sangsi terhadap perlanggaran yang dilakukan siswa. Bagian Kesiswaan tersebut menyusun jadwal pelaksanaan dan jenis pekerjaan dari tugas kompensasi. Di dalam menegakkan disiplin, Wakil Kepala Sekolah SMK Syaikh Zainuddin NW Anjani peranannya sangat besar.

Sebab dengan tugas kompensasi yang telah disusun oleh bidang kesiswaan mampu mendidik siswa dan membuat mereka menjadi berhati-hati dan patuh terhadap peraturan 
sekolah. Padahal patuh terhadap peraturan merupakan dasar dari budaya profesional. Selain hal tersebut di atas, bidang kesiswaan juga berperan membantu memecahkan permasalahan yang timbul pada siswa. Wakil Kepala Sekolah Kesiswaan SMK Syaikh Zainuddin NW Anjani juga bertugas sebagai pembina OSIS. Dalam tugas yang disebutkan terakhir Wakil Kepala Sekolah Kesiswaan telah menjalankan peranannya dalam memupuk jiwa kepemimpinan, membina mental serta mendorong kreatifitas siswa.

Dari pembahasan di atas, dapat diketahui bahwa peranan pimpinan sekolah dalam mengembangkan budaya profesional serta bersama-sama cukup besar. Di dalam menumbuhkan sikap dan perilaku positif yang menjadi dasar budaya profesional menuntut kekompakkan dari seluruh unsur pimpinan sekolah. Langkah-langkah membimbing dan mengarahkan siswa agar berbudaya profesional harus dilakukan bersama-sama. Dengan kata lain akan sulit dicapai hasil yang menggembirakan jika usaha mengembangkan budaya profesional dilakukan pimpinan sekolah secara sendiri-sendiri. Jadi di dalam mengembangkan budaya profesional di sekolah diperlukan peranan pimpinan sekolah secara kolektif. Faktor-Faktor Yang Mempengaruhi Pengembangan Budaya Profesional di Sekolah dibahas sebagai berikut.

Motivasi Siswa. Motivasi siswa disini yang dimaksud adalah dorongan atau keinginan yang kuat pada diri siswa untuk menempuh semua proses pembelajaran di sekolah. Di SMK Syaikh Zainuddin NW Anjani motivasi siswanya dapat dikatakan sangat baik. Hal tersebut tercermin dari ketekunan, kerajinan dan antusias siswa terhadap semua kegiatan di sekolah, baik itu pada pembelajaran teori maupun praktek di masyarakat. Setelah ditanyakan kepada siswa, mereka umumnya menyatakan bahwa sekolah di SMK Syaikh Zainuddin NW Anjani merupakan cita-citanya sejak di MTs.

Dengan demikian meskipun di sekolah tersebut peraturannya sangat ketat, karena memang sudah menjadi cita-citanya maka siswa dapat antusias mengikuti pembelajaran dan patuh terhadap peraturan. Dalam mengembangkan budaya profesional motivasi siswa tersebut sangat menentukan keberhasilannya. Motivasi tersebut mendorong siswa mau melakukan segala upaya untuk mencapai tujuannya. Biasanya orang yang mempunyai keinginan untuk memperoleh sesuatu di dalam dirinya akan terdapat suatu dorongan (motivasi) yang kuat untuk mencapainya. SMK Syaikh Zainuddin NW Anjani motivasi siswa tersebut berupa bermacam-macam tindakan positif. Motivasi siswa untuk bekerja pada waktu pembelajaran praktek misalnya berupa kemauan bekerja dengan cepat, tepat waktu dan hasilnya memenuhi standar. 
Demikian juga motivasi untuk belajar dengan sungguh-sungguh serta motivasi untuk patuh pada tata tertib merupakan wujud dari tindakan positif tersebut. Motivasi pada diri siswa memang dapat ditumbuhkembangkan. Dalam hal ini peranan guru sangat dominan. Guru-guru SMK Syaikh Zainuddin NW Anjani sering menyampaikan pengalaman maupun memberikan pengertian tentang dunia kerja/industri, sehingga siswa mempunyai gambaran positif tentang masa depannya. Dengan demikian akan muncul dalam diri suatu dorongan untuk belajar dengan sungguh-sungguh serta melatih ketrampilan dalam bidangnya sebanyak mungkin. Terhadap siswa yang mengalami kegagalan, guru segera memberi semangat dan dorongan sehingga siswa sadar kembali dan tidak putus asa.

Dikatakan oleh Ibu hikni, guru BK di SMK tersebut : "Terhadap siswa yang bermasalah kami ajak mereka bicara empat mata dan tidak jarang orang tuanya segera dipanggil ke sekolah untuk memecahkan masalahnya”. Motivasi yang kuat adalah yang muncul dari kesadaran diri siswa tersebut. Hal tersebut karena motivasi yang demikian yang tidak mudah luntur. Peranan guru adalah memberi pengertian sehingga siswa sadar akan dirinya, sadar akan tugasnya. Di SMK Syaikh Zainuddin NW Anjani motivasi yang seperti ini yang senantiasa diupayakan para guru dengan jalan memberi pengertian dan menimbulkan kesadaran siswa tentang tugasnya sebagai pelajar.

Etos Kerja Guru. Etos kerja guru dalam pengertian ini yang dimaksud adalah semangat dari guru-guru dalam melaksanakan tugas di sekolah. Di SMK Syaikh Zainuddin NW Anjani etos kerja guru-gurunya cukup membanggakan. Guru-guru senantiasa dapat menempatkan dirinya sebagai pengabdi pada dunia pendidikan. Guru-guru berdisiplin tinggi dan mempunyai komitmen terhadap tugasnya. Tidak pernah ada kasus guru mengeluh karena tugasnya terlalu berat atau tidak cocok. Menurut bagian pengajaran, dalam pembagian tugas mengajar guru, pertimbangan utamanya adalah kemampuan yang dimiliki pada mata pelajaran yang diampunya. Sejak awal pada guru diberikan kebebasan untuk menyampaikan keberatan jika tidak cocok dengan pembagian tugas mengajar, terutama dengan mata pelajaran yang diampunya. Namun selama ini tidak pernah ada yang menyampaikan keberatan.

Etos kerja guru, SMK Syaikh Zainuddin NW Anjani yang cukup tinggi tersebut tidak lepas dari status dan kesejahteraannya. Dengan status sebagai pegawai tetap, sebagai pegawai tetap yayasan. Dengan demikian guru-guru dapat berkonsentrasi pada tugasnya sebagai pendidik dan pengajar. Jarang ditemui guru meninggalkan tugasnya untuk urusan yang lain di luar sekolah. 
Dengan status yang mantap tersebut serta sistem penggajian yang memadahi, tingkat penghasilan guru SMK Syaikh Zainuddin NW Anjani dapat dikatakan cukup baik. Apabila adanya tunjangan dari sekolah sesuai dengan kebijakan yayasan yang membuat tingkat kesejahteraan guru menjadi lebih baik. Dengan kesejahteraan yang cukup guru-guru bisa mengabdi secara penuh kepada yayasan sehingga semua tugas yang dibebankan akan dilaksanakan dengan senang hati tanpa paksaan. Menurut Wakil Kepala Sekolah Bidang Kurikulum :"Guru-guru di sekolah ini tidak ada yang mengeluh dengan tugasnya".

Dalam mengembangkan perilaku positif sebagai dasar budaya profesional, etos kerja guru tersebut sekaligus sebagai contoh bagi pengembangan etos belajar siswa. Etos kerja yang tinggi dari guru-guru SMK Syaikh Zainuddin NW Anjani juga tidak lepas dari kualitas guru-guru itu sendiri. Sebab guru yang mempunyai kualitas yang baik akan mampu melaksanakan tugasnya dengan baik pula. SMK Syaikh Zainuddin NW Anjani kualitas guru-guru baru, yaitu dengan berdasarkan pada kemampuan calon guru. Kualitas terus diupayakan selama guru bertugas di dekolah tersebut dengan berbagai kegiatan misalnya penataran-penataran dan MGMP.

Peran Serta Yayasan. Keikutsertaan pihak yayasan sebagai pengelola SMK Syaikh Zainuddin NW Anjani yang utama adalah menyediakan fasilitas/sarana yang diperlukan bagi penyelenggaraan proses pembelajaran. Siswa SMK bisa profesional apabila telah dibiasakan bekerja dengan mesin-mesin yang kondisinya baik dan jumlahnya cukup, sehingga siswa mempunyai tingkat keterampilan yang tinggi. Yayasan berperan menyediakan fasilitas pembelajaran tersebut.

Peran serta yayasan yang lain adalah dalam hal penilaian terhadap guru dan kepala sekolah. Pihak yang harus mengetahui dan menegaskan penilaian unjuk kerja guru pada DP3. Yayasan juga mengadakan monitoring dan evaluasi terhadap guru dan karyawan baru. Jadi dapat dinyatakan bahwa peran serta yayasan dalam usaha mengembangkan budaya profesional di sekolah sudah cukup besar. Pengembangan budaya profesional tidak dapat dikerjakan dengan baik apabila tidak didukung oleh fasilitas yang memadai. Fasilitas tersebut disediakan terutama oleh pihak yayasan sebagai pengelola sekolah. Yayasan Syaikh Zainuudin NW Anjani sebagai pengelola sekolah ini juga memikirkan kelangsungan sekolah-sekolah di bawah naungannya termasuk SMK Syaikh Zainuddin NW Anjani. Antisipasi dalam hal dana dilakukan Yayasan Syaikh Zainuddin NW Anjani dengan menyisihkan sebagian dana untuk ditabung di bank, dana simpanan tersebut digunakan 
apabila sekolah-sekolah penyangga dana tidak dapat menutup anggaran sekolah-sekolah yang defisit.

Konstribusi Unit Produksi dan Dunia Industri. Keberadaan unit produksi merupakan hal yang sangat penting pada sekolah kejuruan. Berkaitan dengan pengembangan budaya profesional, peranannya amat diperlukan. Unit produksi yang menerima pesanan dari masyarakat/industri merupakan wahana untuk menambah ketrampilan siswa tentang barang-barang industri. Sebab dengan mengerjakan pesanan (order), siswa mempunyai pengalaman mengerjakan barang-barang industri, namun peran serta siswa di dalam Unit Produksi SMK Syaikh Zainuddin NW Anjani masih sangat kecil dan perlu ditingkatkan.

\section{KESIMPULAN}

Kebiasaan-kebiasaan positif yang menjadi dasar budaya profesional dapat dikembangkan di sekolah jika semua elemen di dalam sekolah tersebut mendukung. Faktor yang mempengaruhi pengembangan budaya profesional di sekolah adalah (1) motivasi siswa, (2) etos kerja guru, (3) peran serta yayasan, (4) kontribusi unit produksi dan dunia industri, dan (5) sarana pembelajaran.

\section{SARAN}

Dengan pola pengembangan budaya profesional yang telah dilaksanakan mampu memberikan bekal sikap, mental dan ketrampilan dasar yang memadahi. Namun di dalam dunia kerja nantinya hal tersebut perlu diikuti dengan pengalaman siswa melakukan pekerjaan industri. Disarankan agar siswa lebih dilibatkan dalam unit produksi, mengerjakan pesanan (order) unit produksi, meningkatkan jumlah order dan melakukan sosialisasi unit produksi. 


\section{DAFTAR PUSTAKA}

Hidayat, M. Arief dkk. 1990. Studi Tingkat Profesional Guru dalam Menghadapi Fungsionalisasi Jabatan bagi Guru-guru SMTA di Lingkungan Departemen Pendidikan dan Kebudayaan Daerah Istimewa Yogyakarta. FPTK IKIP Yogyakarta.

Moleong, J Lexy 2000. Metodologi penelitian kualitatif. Bandung : PT. Remaja Rosdakarya. Thoha, Miftah. 1990. Kepemimpinan dalam Manajemen. Jakarta : Rajawali Pers.

Sudjana, Nana dan Ibrahim. 1989. Penelitian dan Penilaian Pendidikan. Bandung: Sinar Baru.

Sahertian, A. 1994. Profil Pendidik Profesional. Yogyakarta : Andi Offset.

Sriningsih, Retno. 1999. Landasan Pendidikan (Pengantar ke arah Ilmu Pendidikan Pancasila).

Joni, T. Raka 1991. Pokok-pokok Pikiran Mengenai Pendidikan guru dalam Mencari Strategi Perkembangan Pendidikan Nasional Menjelang Abad XXI. Jakarta : PT. Gramedia. 